\title{
Optimization of Multiple Effect Evaporators Designed for Fruit Juice Concentrate
}

\author{
Manal A. Sorour \\ Food Eng. and Packaging Dept., Food Tech. Res. Institute, Agric. Res. Center, Giza, Egypt
}

Email address:

manal.sorour@yahoo.com

To cite this article:

Manal A. Sorour. Optimization of Multiple Effect Evaporators Designed for Fruit Juice Concentrate. American Journal of Energy

Engineering. Special Issue: Energy Conservation in Food Industry. Vol. 3, No. 2-1, 2015, pp. 6-11.

doi: 10.11648/j.ajee.s.2015030201.12

\begin{abstract}
The most important running cost item in evaporation is energy. However, energy consumption per unit production can be reduced considerably through the use of multi effect evaporation. A multiple effect evaporation scheme was studied and economically analyzed. Different economic items, including cost of steam and cost of evaporator in addition to annual total cost for single, double, three, four, five and six effects of evaporators were estimated and analyzed. The results indicated that minimum annual total cost is obtained by using a double effect evaporator.
\end{abstract}

Keywords: Multiple Effect Evaporators, Optimum Number of Effects, Annual Cost, Evaporator Cost, Steam Cost

\section{Introduction}

Multiple effect evaporator control is a problem that has been widely reported in the pulp and sugar industries. Therefore evaporation is a very important unit operation and must be controlled smoothly, [1].

Process optimization has always been a noble objective of engineers entrusted with the responsibility for process development and improvement throughout the food industry, [2]. On the other hand, the chemical industry has used cost analysis in several cases in relation to design and process optimization. A classic example in the chemical industry is the determination of the optimal number of effects in evaporation system, were the optimum is found when there is an economic balance between energy saving and added investment, this is, a minimization of the total cost, [3].

Evaporation is the removal of solvent as vapor from a solution. It is the operation which is used for concentration of solution. There could be single effect evaporator or multiple effect evaporators. With addition of each effect steam economy of the system also increases. Evaporators are integral part of a number of process industries like Pulp and Paper, Sugar, Caustic Soda, Pharmaceuticals, Desalination, Dairy and Food Processing etc., [4] described a steady state model of multiple effect evaporators for simulation purpose. The model includes overall as well as component mass balance equations, energy balance equations and heat transfer rate equations for area calculation for all the effects. Each effect in the process is represented by a number of variables which are related by the energy and material balance equations for the feed, product and vapor flow for forward feed. The code has been developed using SCILAB. Results of the present approach are validated with industrial data.

Evaporators are kind of heat transfer equipment where the transfer mechanism is controlled by natural convection or forced convection. A solution containing a desired product is fed into the evaporator and it is heated by a heat source like steam. Because of the applied heat, the water in the solution is converted into vapor and is condensed while the concentrated solution is either removed or fed into a second evaporator for further concentration, [5].

The increase in awareness to cost curtailment of energy consumption coupled with the increase in the consumption of the concentrated and dehydrated food products, energy management has become indispensable in food industries. One such process of obtaining these food products is by employing evaporation in food industries. The process of evaporation is employed in the food industry primarily as a means of bulk and weight reduction for fluids. Therefore, evaporation is one of the most large scale operations in food industry. Energy is the most important running cost item in evaporation. The operating cost of an evaporator system is mostly determined by the energy that is required to achieve certain evaporation rate. Under steady state condition there must be a balance between the energy entering and leaving 
the system. Energy can be saved by reusing vapor formed from the boiling product. One of the few ways of accomplishing such is by multiple-effect evaporation, [6].

Boiling point elevation at a certain external pressure can be determined from a thermodynamic equation using the latent heat of vaporization and molar fraction of the food. However, the use of these equations requires knowledge of the proportions of specific components of the foods that cause changes in the boiling points, [7].

The aim of the work is to explain how total cost of evaporation can be reduced by using multi-effect evaporator and achieve an economically optimal number of effects. This can be proved through application of mass and heat-balance analysis for tomato juice concentration from $5 \%$ to tomato paste $36 \%$.

\section{Experimental Set Up}

\subsection{Determination of Boiling Point Rise}

An experimental procedure was conducted to determine the BPR (boiling point rise). A tomato juice solution of $5 \%$ (wt $\%$ ) concentration was boiled. The concentration was measured at equal intervals of time (15 minutes). The measured concentration was plotted versus temperature difference between boiling point of solution and boiling point of water.

\subsection{Single Effect Evaporator}

Single effect evaporator use more than $1 \mathrm{~kg}$ of steam to evaporate $1 \mathrm{~kg}$ of water. The general configuration for evaporation in this work is schematically represented in (Fig. 1). According to this scheme, the vapor leaving the evaporator is waste, so a single effect evaporator may be considered wasteful of energy, since the latent heat of the leaving vapor is not used but discarded.

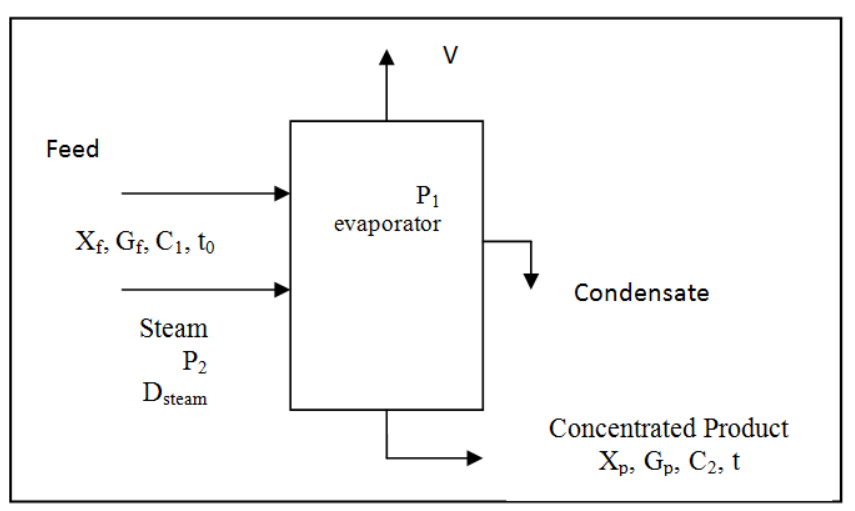

Fig. 1. Simplified Block Flow Diagram for Single Effect Evaporator

\subsection{Simulation Model}

The mathematical model representing the process may be formulated as follows, [8]:-

The amount of concentrated product and the amount of the vapor leaving the evaporator could be calculated by using an overall material balance as follows:

$$
\mathrm{G}_{\mathrm{f}}=\mathrm{G}_{\mathrm{p}}+\mathrm{W}
$$

Where, $G_{f}$ is the flow rate of the feed solution, $\mathrm{kg} / \mathrm{hr}, \mathrm{G}_{\mathrm{p}}$ is the flow rate of the concentrate product, $\mathrm{kg} / \mathrm{hr}, \mathrm{W}$ is flow rate of the vapor leaving the evaporator, $\mathrm{kg} / \mathrm{h}$

To determine $G_{p}$ a component mass balance on solids is needed:-

$$
\mathrm{G}_{\mathrm{f}} \mathrm{X}_{\mathrm{f}}=\mathrm{G}_{\mathrm{p}} \mathrm{X}_{\mathrm{p}}
$$

Where, $\mathrm{X}_{\mathrm{f}}$ is the concentration of tomato juice concentrate entering the evaporator (by weight), $X_{p}$ is the concentration of tomato concentrate product stream (by weight).

The heat load of the evaporator $(\mathrm{Q})$ may be represented by making heat balance on the evaporator:

$$
\mathrm{Q}+\mathrm{G}_{\mathrm{f}} \mathrm{C}_{1} \mathrm{t}_{\mathrm{o}}=\mathrm{WH} \mathrm{H}_{\mathrm{v}}+\mathrm{G}_{\mathrm{p}} \mathrm{C}_{2} \mathrm{t}+\mathrm{Q}_{\text {loss }}
$$

Where $\mathrm{C}_{1}, \mathrm{C}_{2}$ is the specific heat of feed and product solution, $\mathrm{kJ} / \mathrm{kg}$ deg .

Q is the heat load of the evaporator, $\mathrm{kJ} / \mathrm{kg}, \mathrm{H}_{\mathrm{v}}$ is the enthalpy of secondary vapor, $\mathrm{kJ} / \mathrm{kg}$, $\mathrm{t}$ is the boiling point of the product, ${ }^{\circ} \mathrm{C}$, and $\mathrm{t}_{0}$ is the temperature of the feed solution, ${ }^{\circ} \mathrm{C}$

Considering the feed solution as a mixture of concentrated solution (product) and evaporated water, we can write:

$$
\begin{aligned}
\mathrm{G}_{\mathrm{f}} \mathrm{C}_{1} \mathrm{t} & =\mathrm{G}_{\mathrm{p}} \mathrm{C}_{2} \mathrm{t}+\mathrm{WC}_{\mathrm{H} 2 \mathrm{O}} \mathrm{t} \\
\mathrm{G}_{\mathrm{p}} \mathrm{C}_{2} & =\mathrm{G}_{\mathrm{f}} \mathrm{C}_{1}-\mathrm{W} \mathrm{C}_{\mathrm{H} 2 \mathrm{O}}
\end{aligned}
$$

Where, $\mathrm{C}_{\mathrm{H} 20}$ is the specific heat of the liquid water, $\mathrm{kJ} / \mathrm{kg}$ deg. substituting the value of $\mathrm{G}_{\mathrm{p}} \mathrm{C}_{2}$ in equation (3) we obtain:

$$
\mathrm{Q}=\mathrm{G}_{\mathrm{f}} \mathrm{C}_{1}(\mathrm{t}-\mathrm{to})+\mathrm{W}\left(\mathrm{H}_{\mathrm{v}}-\mathrm{C}_{\mathrm{H} 2 \mathrm{O}} \mathrm{t}\right)+\mathrm{Q}_{\text {loss }}
$$

If the heat losses are neglected $\left(\mathrm{Q}_{\text {loss }}=0\right)$, we can write:

$$
\mathrm{Q}=\mathrm{G}_{\mathrm{f}} \mathrm{C}_{1}(\mathrm{t}-\mathrm{to})+\mathrm{W}\left(\mathrm{H}_{\mathrm{v}}-\mathrm{C}_{\mathrm{H} 2 \mathrm{O}} \mathrm{t}\right)
$$

\subsection{Calculation Methods for Multiple-Effect Evaporators}

Multiple-effect evaporation is evaporation in multiple stages, whereby the vapors generated in one stage serve as heating 'steam' to the next stage. Thus, the first stage acts as a 'steam generator' for the second which acts as a condenser to the first and so on. The number of 'effects' is the number of stages thus arranged. The first effect is heated with boiler steam. The vapors from the last effect are sent to the condenser Fig. 2.

The economic and environmental consequences of this result are obvious. In a multi effect evaporator for each kilogram of water evaporated:

1. The quantity of steam consumed is inversely proportional to the number of effects.

2 . The quantity of cooling water utilized in the condenser is inversely proportional to the number of effects.

For heat transfer to occur, a temperature drop must exist at each effect. In other words, the temperature of the vapors generated in a given effect must be superior to the boiling temperature in the following effect: 


$$
\mathrm{T}_{1}>\mathrm{T}_{2}>\ldots \ldots>\mathrm{T}_{\mathrm{n}} \text {, hence: } \mathrm{P}_{1}>\mathrm{P}_{2}>\ldots \ldots \ldots>>>\mathrm{P}_{\mathrm{n}}
$$

In doing calculations for a multiple-effect evaporator system, the values to be obtained are usually the area of the heating surface in each effect, the mass $(\mathrm{kg})$ of steam per hour to be supplied and the amount of vapor leaving each effect. The given or known values are usually as follows:

(1) Steam pressure into first effect,

(2) Final pressure in vapor space of the last effect,

(3) Feed conditions and flow to first effect,

(4) the final concentration in the liquid leaving the last effect,

(5) Physical properties such as enthalpies and/or heat capacities of the liquid and vapors, and

(6) the overall heat transfer coefficients in each effect. Usually the areas of each effect are assumed equal. The calculations are done using material balances, heat balances, and the capacity

$\mathrm{q}=\mathrm{UA} \Delta \mathrm{T}$ for each effect. A convenient way to solve these equations is by trial and error.

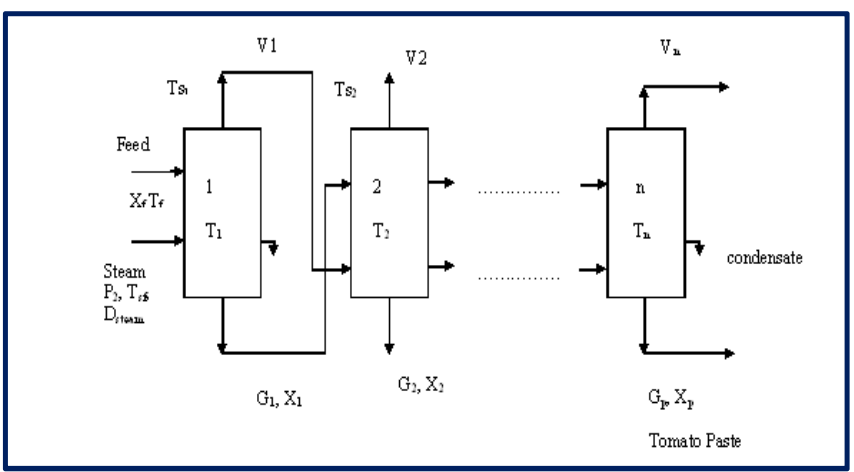

Fig. 2. Multiple Effect Evaporation Equipment (Co-Current)

The Equations representing the process, of multiple effect evaporators may be formulated as follows:

1 - From the known outlet concentration and pressure in the last effect, the boiling point in the last effect can be determined by overall mass balance and component mass balance we can calculate $\mathrm{L}_{1}, \mathrm{~L}_{2}, \ldots \ldots . . \mathrm{L}_{\mathrm{n}}, \mathrm{V}_{1}, \mathrm{~V}_{2}, \ldots \ldots \underline{\mathrm{V}}_{\underline{\mathrm{n}}}$

Where, $\mathrm{L}_{1}, \mathrm{~L}_{2} \ldots \ldots \ldots \mathrm{L}_{\mathrm{n}}$ are the flow rate of solution produced from each effect, $\mathrm{kg} / \mathrm{h}$

$\mathrm{V}_{1}, \mathrm{~V}_{2}, \ldots \ldots \mathrm{V}_{\mathrm{n}}$ are the amounts of vapor produced from each effect, $\mathrm{kg} / \mathrm{h}$

2- The amount of heat transferred per hour in the first effect of a multiple effect evaporator with forward feed in Fig. 2 will be:

$$
\mathrm{q}_{1}=\mathrm{U}_{1} \mathrm{~A}_{1} \Delta \mathrm{T}_{1}
$$

Where $\Delta \mathrm{T}_{1}$ is the difference between the condensing steam and the boiling point of the liquid, $\left(\mathrm{Ts}_{\mathrm{s}} \mathrm{T}_{1}\right)$. Assuming that the solutions have no boiling point rise and no heat of solution and neglecting the sensible heat necessary to heat the feed to the boiling point, approximately all the latent heat of the condensing steam appears as latent heat in the vapor. This vapor then condenses in the second effect, giving up approximately the same amount of heat.

$$
\mathrm{q}_{2}=\mathrm{U}_{2} \mathrm{~A}_{2} \Delta \mathrm{T}_{2}
$$

This same reasoning holds for $\mathrm{q}_{\mathrm{n}}$. Then since $\mathrm{q}_{1}=\mathrm{q}_{2}$ $=\ldots \ldots=\mathrm{q}_{\mathrm{n}}$, then approximately,

$$
\mathrm{U}_{1} \mathrm{~A}_{1} \Delta \mathrm{T}_{1}=\mathrm{U}_{2} \mathrm{~A}_{2} \Delta \mathrm{T}_{2}=\ldots \ldots \ldots=\mathrm{U}_{\mathrm{n}} \mathrm{A}_{\mathrm{n}} \Delta \mathrm{T}_{\mathrm{n}}
$$

Usually, in commercial practice the areas in all effects are equal and

$$
\mathrm{q} / \mathrm{A}=\mathrm{U}_{1} \Delta \mathrm{T}_{1}=\mathrm{U}_{2} \Delta \mathrm{T}_{2}=\ldots \ldots \ldots=\mathrm{U}_{\mathrm{n}} \Delta \mathrm{T}_{\mathrm{n}}
$$

3- Hence, the temperature drops $\Delta \mathrm{T}$ in a multiple effect evaporator are approximately inversely proportional to the values of $\mathrm{U}$. Calling $\Sigma \Delta \mathrm{T}$ as follows with the presence of boiling point rise,

$$
\begin{aligned}
\sum \Delta \mathrm{T} & =\Delta \mathrm{T}_{1}+\Delta \mathrm{T}_{2}+\ldots \ldots+\Delta \mathrm{T}_{\mathrm{n}} \\
& =\mathrm{T}_{\mathrm{sf}}-\mathrm{T}_{5}-\left[(\mathrm{BPR})_{1}+(\mathrm{BPR})_{2}+\ldots . .(\mathrm{BPR})_{\mathrm{n}}\right]
\end{aligned}
$$

Where, $\Delta \mathrm{T}_{1}=$ Available temperature difference for first effect $\left(\mathrm{T}_{\mathrm{sf}}-\mathrm{T}_{1}\right)$.

$\Delta T_{2}=$ Available temperature difference for second effect $\left(\mathrm{Ts}_{1}-\mathrm{T}_{2}\right)$.

$\Delta \mathrm{T}_{5}=$ Available temperature difference for fifth effect $\left(\mathrm{Ts}_{\mathrm{n}-1}-\mathrm{T}_{\mathrm{n}}\right)$.

$\mathrm{T}_{1}=$ Temperature of solution in the first evaporator, ${ }^{\circ} \mathrm{C}$.

$\mathrm{T}_{2}=$ Temperature of solution in the second evaporator, ${ }^{\circ} \mathrm{C}$.

$\mathrm{T}_{\mathrm{n}}=$ Temperature of solution in the (n) evaporator, ${ }^{\circ} \mathrm{C}$.

$\mathrm{T}_{\mathrm{sf}}=$ inlet temperature of the steam to the first effect, ${ }^{\circ} \mathrm{C}$.

$\mathrm{T}_{\mathrm{s} 1}=$ inlet temperature of steam to the second effect, ${ }^{\circ} \mathrm{C}$.

$\mathrm{T}_{\mathrm{sn}}=$ inlet temperature to the $\left(\mathrm{n}^{\text {th }}\right)$ effect, ${ }^{\circ} \mathrm{C}$.

Note that,

$$
\begin{aligned}
\Delta \mathrm{T}_{1}{ }^{\circ} \mathrm{C} & =\Delta \mathrm{T} \mathrm{K}, \Delta \mathrm{T}_{2}{ }^{\circ} \mathrm{C}=\Delta \mathrm{T}_{2} \mathrm{~K}, \Delta \mathrm{T}_{3}{ }^{\circ} \mathrm{C} \\
& =\Delta \mathrm{T}_{3} \mathrm{~K}, \Delta \mathrm{T}_{\mathrm{n}}{ }^{\circ} \mathrm{C}=\Delta \mathrm{T}_{\mathrm{n}} \mathrm{K}
\end{aligned}
$$

Since $\Delta \mathrm{T}_{1}$ is proportional to $1 / \mathrm{U}_{1}$, then:

$$
\Delta T_{1}=\Sigma \Delta T \frac{1 / U_{1}}{1 / U_{1}+1 / U_{2}+\ldots \ldots .+1 / U_{n}}
$$

Similar equations can be written for $\Delta \mathrm{T}_{2}, \Delta \mathrm{T}_{3}, \ldots . \Delta \mathrm{T}_{\mathrm{n}}$

Where, $\mathrm{U}_{1}$ is the heat transfer coefficient for the first effect, $\mathrm{kW} / \mathrm{m}^{2} \mathrm{~K}$

$\mathrm{U} 2$ is the heat transfer coefficient for the second effect, $\mathrm{kW} / \mathrm{m} 2 \mathrm{~K}$

$\mathrm{U} 3$ is the heat transfer coefficient for the third effect, $\mathrm{kW} / \mathrm{m} 2 \mathrm{~K}$

$\mathrm{Un}$ is the heat transfer coefficient for the (n) effect, $\mathrm{kW} / \mathrm{m} 2 \mathrm{~K}$

Any effect that has an extra heating load, such as a cold feed, requires a proportionally larger $\Delta \mathrm{T}$.

4- Using heat and material balances in the first effect, the amount vaporized can be calculated consequently the amount of steam $\left(D_{\text {steam }}\right)$ entering the first evaporator, the value of $q$ transferred in each effect is estimated.

5- Using the rate equation $\mathrm{q}=\mathrm{UA} \Delta \mathrm{T}$ for each effect, we can calculate the areas $A_{1}, A_{2}, \ldots, A_{n}$. The average value $A_{m}$ : 


$$
A_{m}=\frac{A_{1}+A_{2}+\ldots \ldots \ldots+A_{n}}{n}
$$

6- If these areas are reasonably close to each other, the calculations are complete and a second trial is not needed. If these areas are not nearly equal, a second trial should be performed as mentioned above, then obtain new values of $\Delta \mathrm{T}_{1}{ }^{\prime}, \Delta \mathrm{T} 2^{\prime}, \ldots \ldots, \Delta \mathrm{T}_{\mathrm{n}}{ }^{\prime}$ from these equations:

$$
\begin{gathered}
\Delta T_{1}{ }^{\prime}=\frac{\Delta T_{1}+A_{1}}{A m} \\
\Delta T_{2}{ }^{\prime}=\frac{\Delta T_{2}+A_{2}}{A m} \\
\Delta T_{n}{ }^{\prime}=\frac{\Delta T_{n}+A_{n}}{A m}
\end{gathered}
$$

The Sum $\Delta \mathrm{T}_{1}{ }^{\prime}+\Delta \mathrm{T}_{2}{ }^{\prime}+\ldots \ldots+\Delta \mathrm{T}_{\mathrm{n}}{ }^{\prime}$ must equal the original $\sum \Delta \mathrm{T}$. If not, proportionately readjust all $\Delta \mathrm{T}^{\prime}$ values then calculate the boiling point rise in each effect, and as shown before we can get $\mathrm{q}_{1}, \mathrm{q}_{2}, \ldots ., \mathrm{q}_{\mathrm{n}}$ and $\mathrm{A}_{1}, \mathrm{~A}_{2}, \ldots . . \mathrm{A}_{\mathrm{n}}$ using the new values $\Delta \mathrm{T}_{1}{ }^{\prime}+\Delta \mathrm{T}_{2}{ }^{\prime}+\ldots \ldots .+\Delta \mathrm{T}_{\mathrm{n}}{ }^{\prime}$

\section{Cost Estimation}

The various cost items can be expressed in terms of the system-operating variables and parameters as follows, [9]:

\subsection{Annual Cost of Steam}

The steam consumption may be represented according to the following equations:

For single effect evaporator

$$
D_{\text {steam }}=Q / \lambda
$$

For multiple effect evaporator

$$
D_{\text {steam }} \lambda_{s f}+G_{f} C_{p} T_{f}=G_{1} C_{p} T_{1}+V_{1} H_{1}
$$

Where, $D_{\text {steam }}$ is mass flow rate of steam consumption, $\mathrm{kg} / \mathrm{s}$, $\lambda$ is latent heat of vaporization, $\mathrm{kJ} / \mathrm{kg}, \mathrm{G}_{\mathrm{f}}$ is the flow rate of feed solution, $\mathrm{kg} / \mathrm{s}, \mathrm{G}_{1}$ is the flow rate of first effect evaporator, $\mathrm{kg} / \mathrm{s}, \mathrm{T}_{1}$ is temperature of solution in the first effect, ${ }^{\circ} \mathrm{C}, \mathrm{C}_{\mathrm{p}}$ is specific heat of the solution, $\mathrm{kJ} / \mathrm{kg}$.deg., $\mathrm{V}_{1}$ is the amount of vapor produced from first effect, $\mathrm{kg} / \mathrm{h} ., \mathrm{H}_{1}$ is the enthalpy of the vapor leaving the evaporator, $\mathrm{kJ} / \mathrm{kg}, \mathrm{Q}$ is the heat load of the evaporator, $\mathrm{kJ} / \mathrm{s}$

\subsection{Annual Cost of Steam}

$$
\text { Cost of steam }=\mathrm{D}_{\text {steam }} \mathrm{C}_{\mathrm{III}}
$$

Where $\mathrm{C}_{\mathrm{III}}$ is the cost per ton steam, L.E/ton

Annual cost of steam $=$ cost of steam $\mathrm{x}$ Annual operating days $\mathrm{x}$ operating hours

\subsection{Annual Cost of Evaporator}

Annual cost of evaporator may be calculated as follows, [9]:

$$
\begin{aligned}
& \text { Purchased cost }=75228.2(\mathrm{~A})^{0.5053} \\
& \text { Annual cost of evaporator } \\
& =\text { Purchased cost }(1+0.6) 0.15
\end{aligned}
$$

Where, $(1+0.6)$ is the cost of piping and installation, and 0.15 is the depreciation cost. A is the area of heat transfer of the evaporator, calculated according to the equation:

$$
\mathrm{Q}=\mathrm{UA} \Delta \mathrm{T}
$$

Where,

$$
\Delta \mathrm{T} \text { is the driving force }=\left(\mathrm{T}_{\text {steam }}-\mathrm{T}_{\text {boiling }}\right),{ }^{\circ} \mathrm{C}
$$

$\mathrm{U}$ is the overall heat transfer coefficient, $\mathrm{kW} / \mathrm{m}^{2} \mathrm{~K}$

\subsection{Annual Total Cost}

The annual total cost is calculated by applying the following equations: $\begin{aligned} \text { Annual total cost }= & \text { Annual cost of steam }+ \text { Annual cost of } \\ & \text { evaporator, L.E/year }\end{aligned}$

\section{Results and Discussion}

The flow rate and concentration of the feed stream introduced to the evaporator used in this process are fixed for all the cases studied at the following values:

(1) Feed flow rate of Tomato juice $7498.8 \mathrm{~kg} / \mathrm{h}$;

(2) Concentration of the Tomato juice feed 5\% (wt);

(3) Temperature of the feed solution $30^{\circ} \mathrm{C}$;

(4) The product (Tomato paste) leaving at $36 \%$

\subsection{Determination of Boiling Point Rise}

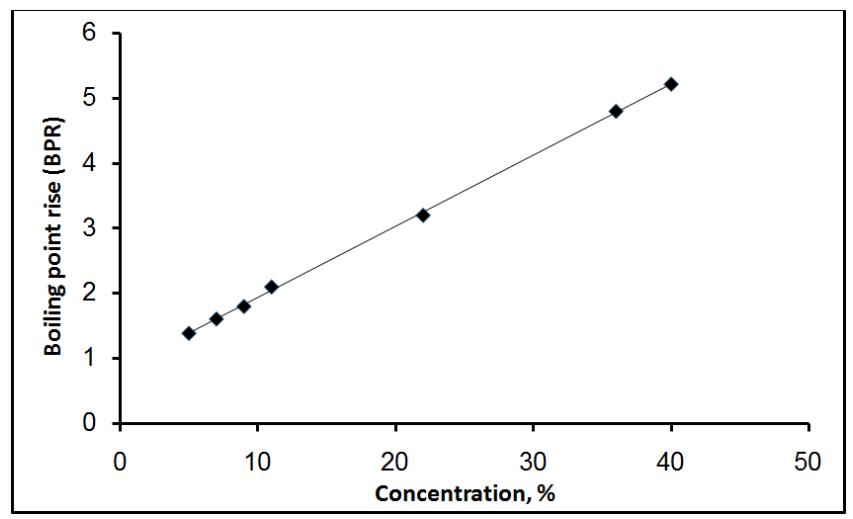

Fig. 3. Boiling Point Rise Of Tomato Juice Solutions

In the majority of cases in evaporation, the thermal properties of the solution being evaporated may differ considerably from those of water. The concentrations of the solutions are high enough so that the heat capacity and boiling point are quite different from that of water. Boiling 
point rise expresses the difference (usually in ${ }^{\circ} \mathrm{F}$ ) between the boiling point of a constant composition solution and the boiling point of pure water at the same pressure, [10].

Table 1 shows the cost items of single and multiple effect evaporators. The results observed that annual cost of steam decrease with increasing number of evaporator effects, while annual cost of evaporators increase with increasing the number of evaporator effects. However the minimum total cost of evaporation will be at the economically optimal number of effects which is double effect evaporator as shown in Fig. 4

Table 1. Cost Items of Single And Multiple Effect Evaporators

\begin{tabular}{llll}
\hline $\begin{array}{l}\text { No. of } \\
\text { effects }\end{array}$ & $\begin{array}{l}\text { Annual cost } \\
\text { of steam }\end{array}$ & $\begin{array}{l}\text { Annual cost } \\
\text { of evaporator }\end{array}$ & $\begin{array}{l}\text { Annual total } \\
\text { cost }\end{array}$ \\
\hline 1 & 1382480 & 131651.8973 & 1514131.897 \\
2 & 1091426 & 288676.4304 & 1380102.43 \\
3 & 933120 & 526209.804 & 1459329.804 \\
4 & 861280 & 767122.4444 & 1628402.444 \\
5 & 766000 & 1044717.771 & 1810717.771 \\
6 & 593000 & 1343161.957 & 1936161.957 \\
\hline
\end{tabular}

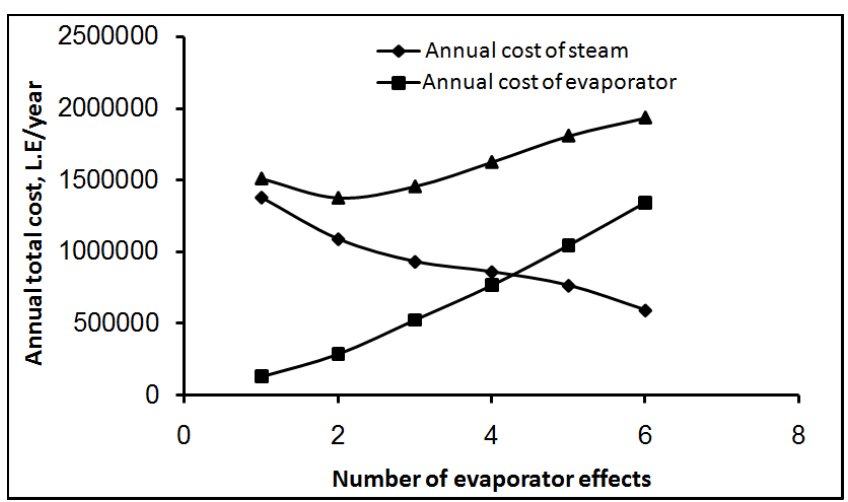

Fig. 4. Optimal Number of Effects

\section{Sample Calculation}

\subsection{Double Effect Evaporator}

As an example of calculation, a double effect evaporator is schematically represented in (Fig. 5).

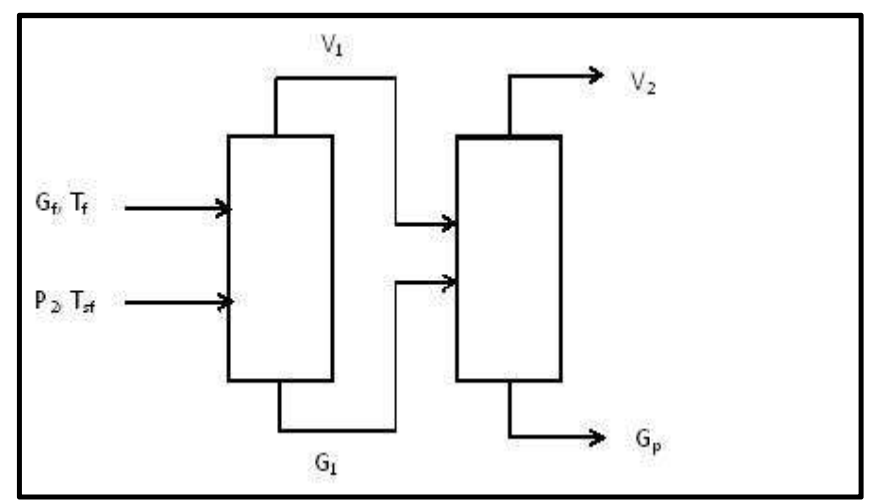

Fig. 5. Simplified Block Flow Diagram for Double Effect Evaporator
This sample simulates the double effect schemes of evaporator using the operating conditions $\left(\mathrm{G}_{\mathrm{p}}, \mathrm{X}_{1}, \mathrm{X}_{2}, \mathrm{P}_{1}, \mathrm{P}_{2}\right)$ of the "Paste and Juice Company at Egypt" aiming at cost calculations with aim of item estimation as mentioned before.

- Material and component balance on first effect and second effect

$$
\begin{aligned}
& \mathrm{G}_{1}=0.4734 \mathrm{~kg} / \mathrm{s} \\
& \mathrm{V}_{1}=1.6096 \mathrm{~kg} / \mathrm{s} \\
& \mathrm{V}_{2}=0.1841 \mathrm{~kg} / \mathrm{s}
\end{aligned}
$$$$
\text { - } \sum \Delta T=T s f-T_{2}-\left(B P R_{1}+B P R_{2}\right)
$$

From figure $3 \mathrm{BPR}_{1}$ and $\mathrm{BPR}_{2}$ are 3.2, 4.8 respectively $\mathrm{T}_{\mathrm{sf}}=120^{\circ} \mathrm{C}$ at $\mathrm{P} 2$ (steam entering the first evaporator) $=2 \mathrm{bar}$ $\mathrm{T}_{2}=50^{\circ} \mathrm{C}$ from Company

$$
\sum \Delta T=62^{\circ} \mathrm{C}
$$

- From equations (14): $U_{1}$ and $U_{2}$ are 2.1, 1.04 (respectively from company)

$$
\begin{gathered}
\sum \Delta T_{1}=28.5302^{\circ} \mathrm{C} \\
\sum \Delta T_{2}=33.4697^{\circ} \mathrm{C} \\
\mathrm{T}_{1}=\mathrm{T}_{\mathrm{sf}}-\Delta \mathrm{T}_{1}=120-28.5302=91.4698^{\circ} \mathrm{C} \\
\mathrm{T}_{2}=\left(\mathrm{T}_{1}-\mathrm{BPR}_{1}\right)-\Delta \mathrm{T}_{2}=54.8^{\circ} \mathrm{C} \\
\mathrm{T}_{\mathrm{s} 1}=\mathrm{T}_{1}-\mathrm{BPR}_{1}=88.2698^{\circ} \mathrm{C} \\
-\quad \lambda_{\mathrm{sf}} \text { at }\left(120^{\circ} \mathrm{C}\right)=2202.3 \mathrm{~kJ} / \mathrm{kg}(\text { from steam table }) \\
\lambda_{\mathrm{s} 1} \text { at }\left(88.2696^{\circ} \mathrm{C}\right)=2656.82 \mathrm{~kJ} / \mathrm{kg} \\
\mathrm{C}_{\mathrm{p}} \text { for tomato juice }=4.17 \mathrm{~kJ} / \mathrm{kg} . \mathrm{deg}, \mathrm{H}_{1} \text { at Ts } \mathrm{T}_{1}=2656.82 \\
\mathrm{~kJ} / \mathrm{kg} \\
\text { From equation }(20): \mathrm{D}_{\text {steam }}=1.9047 \mathrm{~kg} / \mathrm{h} \\
\mathrm{q}_{1}=\mathrm{D}_{\text {steam }} \lambda_{\mathrm{sf}}=4194.721 \mathrm{~kJ} / \mathrm{s} \\
\mathrm{q}_{2}=\mathrm{V}_{1} \lambda_{\mathrm{s} 1}=3683.52 \mathrm{~kJ} / \mathrm{s}
\end{gathered}
$$

- From equation (8):

$$
\begin{gathered}
q_{1}=U_{1} A_{1} \Delta T_{1}, q_{1}=U_{2} A_{2} \Delta T_{2} \\
\mathrm{~A}_{1}=120.5144 \mathrm{~m}^{2} \text { and } \mathrm{A}_{2}=105.824 \mathrm{~m}^{2} \\
\text { From equation (15): } A_{m}=\frac{A_{1}+A_{2}}{2}
\end{gathered}
$$

From equation (16-18): $\Delta T_{1}^{\prime}=30.38^{\circ} \mathrm{C}, \Delta T_{2}^{\prime}=31.297^{\circ} \mathrm{C}$

$$
\begin{aligned}
& -T_{1}=T_{s f}-\Delta T_{1}^{\prime}=120-30.38=89.62^{\circ} \mathrm{C} \\
& T_{2}=\left(T_{1}-B P R_{1}\right)-\Delta T_{2}^{\prime}=(89.62-3.2)-31.297=55.123^{\circ} \mathrm{C}
\end{aligned}
$$

$$
T_{s 1}=T_{1}-B P R_{1}=86.42^{\circ} \mathrm{C}
$$


- $\lambda_{\text {sf }}$ at $120^{\circ} \mathrm{C}=2202.3 \mathrm{~kJ} / \mathrm{kg}$ (from steam table)

$$
\lambda_{\mathrm{s} 1} \text { at } 86.42^{\circ} \mathrm{C}=2293.64 \mathrm{~kJ} / \mathrm{kg}
$$

As shown before:

$$
\begin{aligned}
& q_{1}^{\prime}=4194 \mathrm{~kJ} / \mathrm{s} \text { and } q_{2}^{\prime}=3691.843 \mathrm{~kJ} / \mathrm{s} \\
& \mathrm{A}_{1}=113.176 \mathrm{~m}^{2} \text { and } \mathrm{A}_{2}=113.427 \mathrm{~m}^{2}
\end{aligned}
$$

- From equations (21-27) operating hours in the company $=7200 \mathrm{~L} . \mathrm{E} / \mathrm{year}$

$$
\text { Annual cost of steam }=987033.6 \text { L.E/year }
$$

- Cost of first evaporator

$$
\begin{gathered}
\text { Purchased cost }=75228.2(113.176)^{0.5053}=820621.21 \\
\text { L.E } / \text { year }
\end{gathered}
$$

Annual cost $=820621.21 \times 1.6 \times 0.15=196949.0908$ L.E $/$ year

The same for the second evaporator Annual cost $=196949.09$

$$
\text { L.E/year }
$$

$$
\text { Annual total cost }=1380931.78 \mathrm{~L} \cdot \mathrm{E} / \mathrm{year}
$$

The three, four,......seven effect evaporator can be calculated in the same trend as shown from the previous example of double effect evaporator.

\section{Conclusion}

A classic example in the chemical industry is the determination of the optimal number of effects in an evaporation system, were the optimum is found when there is an economic balance between energy saving and added investment, this is, a minimization of the total cost. The results observed that as number of effects of evaporators increased, annual cost of steam decreases and annual cost of evaporator increases. The optimum total cost for tomato juice concentration, in which the tomato juice enters at $5 \%$ and must be processed to $36 \%$ was by using double effect evaporator.

\section{References}

[1] P. D. Smith, C.L. E. Swartz and S. T. L. Harrison, Control and Optimization of a Multiple effect evaporator, Proc. S. Afr. Sug. Technol. Ass., 2000, 74, pp. 274-279

[2] H. Nuñez1, R. Simpson, S. Almonacid, and A. Abakarov, A study of different multi effect evaporators designed for Thermal processing of tomato paste: optimization and quality Evaluation", International Conference in Food Innovation, 2010.

[3] D. Kern, Procesos de Transferencia de Calor. Editorial Continental, S.A. México, 1999

[4] J. S. Dhara, G. Bhagchandanc, Design, Modelling and Simulation of Multiple Effect Evaporators. International Journal of Scientific Engineering and Technology, 2012, 1, pp.01-05.

[5] V. Jaishree, Optimization of a multiple Effect Evaporator System, A Thesis submitted to the National Institute of Technology, Rourkela In partial fulfillment of the requirements of Bachelor of Technology (Chemical Engineering) Department of Chemical Engineering National institute of technology, Rourkela, Orissa, 2010, pp. 769, India.

[6] S. Gunajit, D. B. Surajit, Energy Management in MultipleEffect Evaporator System: A Heat Balance AnalysisApproach, Gen. Math. Notes, 2010, 1, pp. 84-88

[7] G.V. Barbosa-Cánovas, P. Juliano and M. Peleg. Engineering properties of foods, In: Food engineering. Encyclopedia of life support sciences, Barbosa-Cánovas G.V. (Ed.). EOLSS Publishers/UNESCO, Paris, France, 2005.

[8] M. A. Sorour, A comparative study of energy conservation methods in juice concentration by evaporation, Faculty of Eng., Cairo University, 2001, pp. 57-66.

[9] M. S. Peter, K. D. Timmerhaus, Plant Design and Economics for Chemical Engineers, 4th Ed., McGraw Hill, New York, 1991.

[10] B. G. Liptak, Process Control Trends, Control, March, May, and July, 2004. 